\title{
Teknik Isolasi DNA Sel Hati Ayam Secara Tradisional
}

\author{
Asriah Nurdini Mardiyyaningsih \\ Pendidikan Biologi, FKIP Universitas Tanjungpura
}

\begin{abstract}
Abstrak
Perkembangan biomolekuler yang cepat menyebabkan pemahaman mengenai konsep DNA perlu ditanamkan sejak awal, terutama pada siswa sekolah menengah. Konsep DNA dapat diajarkan melalui teknik isolasi DNA secara tradisional. Teknik ini dapat dilakukan dengan menggunakan peralatan dan bahan sederhana dan tanpa protokol yang rumit. Tujuan praktek ini adalah menggunakan teknik isolasi DNA secara tradisional dengan menggunakan bahan isolasi DNA berupa hati ayam yang mudah diperoleh, dan enzim protease yang diperoleh dari ektraksi mandiri sel daun pepaya. Pada akhir proses isolasi diperoleh DNA, namun DNA yang didapatkan merupakan gabungan antara DNA hati ayam dan DNA sel daun pepaya. Kesimpulan dari praktek ini adalah teknik isolasi DNA tradisional dapat dilakukan untuk mengisolasi DNA dari sel hati ayam meskipun tidak dapat dibuktikan secara meyakinkan bahwa DNA yang diisolasi itu murni hanya berasal dari DNA inti sel hati ayam.
\end{abstract}

Kata kunci : teknik isolasi, dna, hati ayam, tradisional

\section{Pendahuluan}

Perkembangan biomolekuler, yang secara umum mencakup manipulasi DNA dan RNA berkembang semakin cepat dan merambah ke dalam berbagai bidang kehidupan masyarakat. Kemajuan perkembangan bidang biomolekuler ini dipicu oleh ditemukannya struktur molekul DNA oleh Watson dan Crick pada tahun 1953 (Azhar, 2008; Muladno, 2002). Bidang kesehatan dan pertanian merupakan bidang yang paling banyak diuntungkan dengan kemajuan bioteknlogi ini, misalnya aplikasi rekayasa DNA dan RNA dalam penyediaan hormon insulin atau untuk pembuatan tanaman transgenik (Muladno, 2002). Karena perkembangannya yang cepat dan merambah berbagai sektor kehidupan manusia, maka perkembangan bioteknologi menjadi salah satu materi yang penting untuk dikuasai oleh tidak saja mahasiswa tingkat sarjana yang tertarik pada pengembangan ilmu biologi dan biomolekuler, namun juga oleh siswa sekolah menengah. Di Indonesia, pembelajaran mengenai DNA sebagai material genetik telah dimulai dari kelas 3 SMP.

Pada pembelajaran di sekolah menengah di Amerika, pengetahuan mengenai DNA sebagai bahan utama rekayasa genetika telah diberikan. Untuk memvisualisasikan DNA dan meyakinkan siswa bahwa DNA itu 
ada, Marek et al., (2009) memberikan cara pengekstrakan DNA dari makhluk hidup yang ada di sekitar sekolah untuk dimanfaatkan sebagai pembelajaran pengetahuan awal siswa mengenai DNA. Siswa pada berbagai level sekolah sangat tertarik dengan bentuk DNA. Siswa di sekolah menengah pun telah mulai dapat diperkenalkan pada DNA dengan cara melakukan ekstraksi DNA dari sel secara sederhana, yang melibatkan bahan dan alat dapur sederhana yang mudah diperoleh dan disiapkan oleh siswa dan tidak menuntut biaya yang terlalu mahal. Teknik ini dikenal dengan teknik isolasi DNA secara tradisional (Marek et al., 2009). Dengan menggunakan teknik ini guru dapat melakukan isolasi DNA dengan menggunakan bahan-bahan sederhana yang mudah ditemukan serta tanpa harus mengikuti protokol preparasi yang memerlukan kondisi steril dan rumit.

Bahan isolasi DNA tidak rumit untuk ditemukan. Makhluk hidup (baik uniseluler ataupun multiseluler) merupakan bahan penyedia DNA. Pada dasarnya, DNA, sebagai unit kehidupan terkecil, terdapat pada semua makhluk hidup mulai dari mikroorganisme sampai organisme tingkat tinggi seperti manusia. DNA dapat ditemukan pada sel dan dalam inti sel. DNA yang terdapat dalam sel berupa DNA mitokondria, DNA kloroplas, sedangkan DNA yang terdapat dalam inti sel disebut DNA inti (Muladno,2002). Dalam hal ini hati ayam dapat pula digunakan sebagai salah satu bahan isolasi DNA, karena selain dapat disediakan dalam jumlah cukup besar, hati ayam juga cukup mudah didapat dan mudah dipreparasi.

Dalam mengisolasi DNA secara tradisional, Marek et al., (2009) menggunakan bahan-bahan dapau berupa garam, sabun cuci dan protease yang berasal dari meat tenderizer. Meat tenderizer jarang digunakan di Indonesia sebagai pengempuk daging. Secara tradisional, banyak ibu rumah tangga justru menggunakan bungkusan daun pepaya untuk melunakkan daging. Papain dalam pepaya dalam hal ini berfungsi sebagai protease. Oleh karenanya, penggunaan meat tenderizer dapat diganti dengan ekstrak papain.

Tujuan penelitian ini adalah untuk melihat keberhasilan pelaksanaan teknik isolasi DNA secara tradisional dengan menggunakan bahan berupa sel hati ayam dan diberikan protease berupa papain yang diekstraksi mandiri dari sel daun pepaya secara sederhana.

\section{Metode Penelitian}

\section{Pembuatan enzim protease papain}

Daun pepaya sebanyak 100 gr ditambah dengan air es kemudian digerus dalam lumpang dan mortar ukuran besar hingga cukup halus. Pada saat penggerusan, air es terus ditambahkan. Tambahkan air es hingga volumenya setengah dari volume lumpang. Selanjutnya cairan daun pepaya tersebut disaring menggunakan kain kasa. 


\section{Preparasi DNA dari hati ayam.}

Hati ayam 100 gr dipotong berukuran besar dan ditaruh dalam lumpang. Kemudian kedalamnya diberikan air es dan garam sebanyak setengah sendok teh. Selanjutnya bahan-bahan tersebut digerus bersama menggunakan lumpang dan mortar hingga halus. Tambahkan 1 sendok teh sunlight, aduk hingga menjadi kental dan berlendir. Tambahkan air es hingga menjadi lebih encer, namun tetap berlendir. Diamkan selama 15 menit. Pindahkan larutan kedalam tabung reaksi hingga ketinggiannya dari dasar tabung mencapai $\pm 2 \mathrm{~cm}$.

\section{Isolasi DNA}

Campurkan dengan enzim papain dengan volume larutan 1:1. Tambahkan $10 \mathrm{ml}$ etanol $70 \%$ secara perlahan melalui dinding tabung. Ambil bagian berwarna putih yang timbul setelah pemberian etanol dan lihat di bawah mikroskop.

\section{Hasil dan Pembahasan Hasil}

Hasil isolasi DNA berupa larutan berwarna keputihan yang tampak menggumpal, tak larut dan berada di antara campuran enzim papain-organ hati ayam dan alkohol $70 \%$. DNA tak dapat larut dalam alkohol, sehingga terlihat menggumpal seperti kapas (Gambar 1). Hasil isolasi tersebut kemudian dilihat di bawah mikroskop untuk diamati. Hasil pengamatan menunjukkan bahwa DNA tersebut berwarna keputih-putihan dan berpilin (Gambar 2).

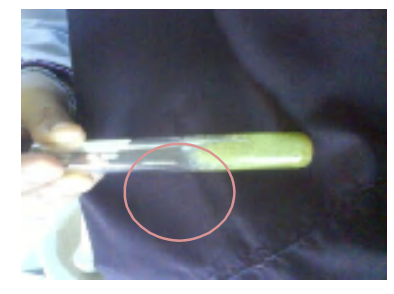

Gambar 1. Hasil isolasi DNA

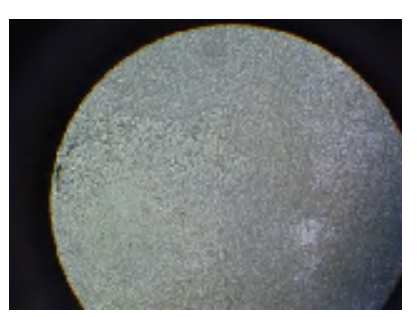

Gambar 2. DNA hasil isolasi dilihat (warna putih) pada tabung percobaan di bawah mikroskop

\section{Pembahasan}

Hasil penelitian menunjukkan bahwa prosedur yang digunakan dalam isolasi DNA tradisional di atas dapat diterapkan untuk mengisolasi DNA. Hasil isolasi pada tabung reaksi menunjukkan adanya pemisahan yang jelas antara DNA dengan supernatan pada tabung reaksi. Pita atau benang DNA yang dihasilkan pada isolasi ini tampak sebagai gumpalan benang berwarna putih (Gambar 1). Marek et al., (2009) menyebutkan bahwa pita DNA dari hasil isolasi DNA tradisional mengikuti prosedurnya terdapat sebagai gumpalan pita berwarna putih, yang sesuai dengan yang ditemukan pada isolasi DNA tradisional dengan prosedur di atas. Gumpalan pita DNA yang diamati di bahwa mikroskop tampak sebagai berkas benang yang panjang dan berpilin (Gambar 2). 
DNA terdapat di dalam sel, tepatnya terlindung dalam nukleus (inti sel) Batas inti dengan organel lainnya di dalam sel adalah membran sel. Sednagkan sel sendiri dibatasi oleh membran sel dengan senyawa ekstraseluler (Cullen, 2002). Dengan demikian, untuk mendapatkan dan mengisolasi molekul DNA, langkah pertama yang harus dilakukan adalah menghancurkan (melisiskan) membran sel dan membran inti. Tahapan isolasi DNA dari organisme eukariot menurut Muladno (2002) setelah tahap lisis adalah pemusnahan protein dan RNA, serta pemurnian DNA.

Pelisisan sel dilakukan dengan menguraikan membran sel yang membatasi sel dengan lingkungan luar, dan melisiskan membran inti. Marek et al., (2009) menganjurkan menggunakan deterjen untuk melisiskan membran. Namun dalam perlakuan ini digunakan penggerusan dan garam sebagai pelisis sel. Penggerusan merupakan salah satu cara fisik penghancuran sel selain sonar (sonicating) (Wikipedia, 2008). Untuk membantu proses pelisisan sel digunakan garam. Lodish et al., (tanpa tahun) mengatakan bahwa perlakuan kultur sel dengan larutan buffer garam dapat mengekstraksi protein yang terlarut air dan protein integral pada membran. Hal ini merupakan salah satu perlakuan untuk merusak membran sel. Umumnya, protein perifer dapat dihilangkan dari membran menggunakan larutan yang mengandung konsentrasi ion tinggi (dalam hal ini konsentrasi garam yang tinggi) yang dapat menghancurkan ikatan ion, atau dengan bahan kimia yang mengandung kation seperti $\mathrm{Mg}^{2+}$.

Penggerusan dan penambahan garam dilakukan pada saat sel hati ayam telah diberikan air es. Es disini berfungsi untuk menurunkan suhu sel-sel hati ayam. Penurunan suhu ini dimaksudkan untuk menghambat kerja enzim endonuklease bawaan sel. Menurut Campbell et al., (2004), enzim endonuklease adalah salah satu enzim dari enzim hidrolisis lainnya yang terdapat di dalam lisosom. Endonuklease bekerja untuk memotong-motong DNA pada urutan nukleotida tertentu (Yatim, 2003). Umumnya ini dilakukan terhadap DNA asing lain yang masuk ke dalam sel. Namun apabila membran lisosom rusak, dan enzim terdapat bebas, maka ditakutkan enzim akan merusak DNA sel sendiri, seperti yang terjadi pada proses autofagi. Agar enzim ini tidak dapat bekerja, maka suhu larutan dijaga berada di bawah suhu fungsional endonuklease dengan cara memberikan es.

Tahapan selanjutnya adalah pemberian sabun cuci. Sabun cuci cair di sini berfungsi untuk melisiskan membran dan menghilangkan molekul lain selain DNA yang diinginkan. Lipid akan terlarut dalam sabun cuci. Fosfolipid yang terdapat pada membran sel dan membran inti akan terlarut dalam larutan sabun. Molekul lain yang berikatan dengan lipid pun dapat ditangkap dan dilarutkan oleh larutan sabun, sehingga yang tertinggal hanyalah 
DNA sel saja. Proses ini optimal dengan membiarkannya selama 10-15 menit.

DNA yang mengapung bebas dalam cairan, masih terikat oleh protein pengunci yang disebut histon (Campbell et al., 2004). Untuk menghilangkan histon, digunakan enzim protease. Enzim protease dapat diperoleh dengan mudah dari papain, atau meat tenderizer (Marek et al., 2009). Dalam hal ini pemakaian papain lebih menguntungkan karena papain juga dapat bertindak untuk menghancurkan endonuklease (Marek et al., 2009). Papain dapat dibuat sendiri dengan cara mengekstraksinya dari daun pepaya. Secara umum ekstraksi papain dilakukan dengan menggerus daun pepaya. Marek et al. (2009) menyatakan bahwa penggerusan merupakan salah satu cara untuk menghilangkan dinding sel dari sel daun pepaya, sehingga isi selnya dapat diperoleh. Untuk membantu menginaktifkan sementara enzim papain selama ektraksi, digunakan penambahan air es.

Ekstrak papain kemudian dicampurkan dengan larutan DNA yang sudah diberi sabun. DNA yang tidak berikatan lagi dengan histon akan lebih mudah terpresipitasi (terpisah) karena tidak ada lagi protein yang mengikatkan dengan lingkungan air (Marek et al., 2009). Penambahan etanol, suatu senyawa yang tidak melarutkan DNA, mempermudah visualisasi DNA. Etanol (EtOH) $\quad 70 \% \quad$ akan menyebabkan DNA mengalami presipitasi dan muncul sebagai pita putih yang berada pada larutan antara alkohol dan larutan sabun.

Untuk melihat dengan jelas, DNA diambil menggunakan pipet dan dilihat di bawah mikroskop. Walaupun terlihat ada benang putih yang memanjang, namun pembuktian DNA dengan teknik ini hanyalah dapat dilakukan berdasarkan teori bahwa ketika kita sudah menghilangkan protein, karbohidrat dan lipid melalui protokol yang dilaksanakan, maka yang tersisa hanyalah DNA. Karena alasan di atas, Marek et al. (2009) menyarankan agar guru mendampingi siswa untuk mendapatkan pemahaman mengenai DNA melalui bantuan teori daripada hanya membiarkan siswa melakukan praktek sendiri. Kemurnian DNA yang didapatkan dengan teknik isolasi tradisional ini juga patut dipertanyakan. Karena ada kemungkinan pencampuran antara DNA sel hati ayam dengan DNA sel daun pepaya. DNA sel hati ayam dapat berupa DNA inti dan DNA mitokondria, sedangkan DNA sel daun pepaya dapat berupa DNA inti, DNA mitokondria dan atau DNA kloroplas (Campbell et al., 2004).

Meskipun terdapat kekurangan, namun kelebihan isolasi DNA dengan teknik tradisional ini, yakni peralatan dan bahan yang sederhana, serta protokol pelaksanaan yang tidak terlalu rumit, sangat cocok untuk digunakan sebagai sarana mempelajari atau menimbulkan pengetahuan awal mengenai DNA bagi siswa sekolah menengah. 


\section{Kesimpulan}

Teknik isolasi DNA tradisional dapat dilakukan untuk mengisolasi DNA dari sel hati ayam meskipun tidak dapat dibuktikan secara meyakinkan bahwa DNA yang diisolasi itu murni hanya berasal dari DNA inti sel hati ayam.

\section{Daftar Pustaka}

Azhar, T.N. 2008. Dasar-Dasar Biologi Molekuler: Menelusuri jejak hayati dari asam nukleat ke protein dan keajaiban bioteknologi. Cetakan 1. Widya Padjajaran. Bandung.

Campbell, N.A., J.B. Reece, dan L.G. Mitchell. 2004. Biologi. Jilid 1. $5^{\text {th }}$ ed. Diterjemahkan oleh Dra. Rahayu Lestari, dkk. Erlangga. Jakarta.
Lodish, H., A. Berk, P. Matsudaira, C. A. Kaiser, M. Krieger, M.P. Scott, L. Zipursky, dan J. Darnell. Tanpa tahun. Molecular Cell Biology. $5^{\text {th }}$ ed. http://bcs.whfreeman.com/lodish 5e/default.asp?s $=\& \mathrm{n}=\& \mathrm{i}=\& \mathrm{v}=\& \mathrm{0}$ $=\& \mathrm{~ns}=0 \& \mathrm{t}=\& u i d=0 \& \mathrm{rau}=0$. diakses tanggal 20 Mei 2009.

Marek, E., C. Mulvihill, dan D. Bell. 2009. Extracting The Max From A DNA Extraction. Science Scope. Volume 32 Nomor 5 Edisi Januari 2009. USA.

Muladno. 2002. Seputar Teknologi Rekayasa Genetika. Pustaka Wira Usaha Muda. Bogor.

Yatim, W. 2003. Kamus Biologi. Yayasan Obor Indonesia. Jakarta. Yuwono, T. 2005. Biologi Molekuler. Penerbit Erlangga. Jakarta. 